\title{
Analysis of Climate Variability and Its Influence on the Hydrological Response of the Catchment Area of Kadey (East Cameroon)
}

\author{
Kaledje Paulin Sainclair Kouassy¹, Ngoupayou Jules-Rémy Ndam1, Amidou Kpoumie², \\ Takounjou Alain Fouepe ${ }^{3}$, Ondoua Joseph Mvondo ${ }^{1}$ \\ ${ }^{1}$ Laboratory of Engineering Geology and Alterology, Faculty of Science, University of Yaounde 1, \\ Yaounde, Cameroon \\ ${ }^{2}$ Department of Earth Sciences, Faculty of Science, University of Maroua, Maroua, Cameroon \\ ${ }^{3}$ Institute of Geological and Mining Research, Hydrological Research Centre, Yaounde, Cameroon \\ Email: kkaledje@yahoo.fr
}

Received 6 February 2016; accepted 24 April 2016; published 27 April 2016

Copyright (C) 2016 by authors and Scientific Research Publishing Inc.

This work is licensed under the Creative Commons Attribution International License (CC BY).

http://creativecommons.org/licenses/by/4.0/

\section{(c) (i) Open Access}

\section{Abstract}

Register in the framework of the International Program of Research on Water Resources Management and Protection of Ecosystems, the Congo basin in which lies the catchment area of the Kadey (2647 km2) was selected to better assess the impact climate variability on the water surface in the perspective of supply drinking water both in the rainy season and in periods of low water. Based on new data from rainfall and flow rates obtained in the last fifteen years (19982013), the major trends in time series and the scope of the "drought" were identified. The historical rainfall in the basin is characterized by two major ruptures rainfall in 1969 and 1999. These have generated an order deficit of $14 \%$ respectively and an excess of nearly $19 \%$. These phenomena also affected the recurrence of cumulative rainfall throughout the Kadey basin. Here, the hydrological response to excess rainfall is over $\mathbf{1 0 0 \%}$. However, it appears that over the period 1970-2012, the number of years that has undergone a "severe drought" is to play down.

\section{Keywords}

Catchment Area of Kadey, Climate Variability, Surface Water, Hydrological Response 


\section{Introduction}

Cameroon and Central Africa under mousson regime, is a vast complex where the climate is governed by the movement of the Atlantic mousson. This part of Africa is hit in recent decades by a more or less severe drought as the climate is equatorial, tropical humid and semi-arid [1]-[3]. This decrease in current rainfall since the beginning of the 70s seems to be the consequence of strong climate variability because of a likely disruption of the West African mousson [3]. It is characterized by a decrease of about $15 \%$ to $20 \%$ of the rainfall and an even greater decline in stream flow [4] [5].

However, this background of general decline hydroclimatic is upset for example by increasing the speed of the Oubangui River (Central African Republic) since 1970 despite a significant rainfall deficit [5] [6]. This hydrological paradox is also observed in Gabon and Central African Republic in equatorial climate through an increase in groundwater level over the last 50 years around small endorheic ponds and rivers [5] [7].

The catchment area of Kadey is a sub-watershed of the Congo drained by the river with many tributaries Kadey as Boumbe II, Mama, Kudu and Doume rivers. The aim is to better characterize climate variability through rainfall across the basin and assess its hydrological response from the flow variations at the outlet.

\section{On Presentation of the Study Area}

The catchment area of Kadey (2 $647 \mathrm{~km}^{2}$ ) is located in Eastern Cameroon, between longitudes $14^{\circ} 29 ' \mathrm{E}$ and $14^{\circ} 45^{\prime} \mathrm{E}$ and the latitudes $4^{\circ} 12^{\prime} \mathrm{N}$ and $4^{\circ} 36^{\prime} \mathrm{N}$ (Figure 1). The basin is located in the equatorial climate transition upstream from the part of the basin located south of the Sanaga. As for the entire Congo Basin, annual average rainfall is $1428.9 \mathrm{~mm}$ between 1960s and 2013s. The rainfall pattern has four seasons marking the equatorial influence. The distribution of seasons varies following stations. However, the aspect "camel's back" characterizes all stations of the Sangha Basin, with two maxima and two minima well marked. The second maxima is always most powerful. The highest temperatures are observed between March and April and are respectively $25.4^{\circ} \mathrm{C}$ Batouri, $25.9^{\circ} \mathrm{C}$ to $26^{\circ} \mathrm{C}$ and Dem Bertoua. In terms of the lowest temperatures, they correspond to the months of July and August, with $23^{\circ} \mathrm{C}$ in Batouri, Bertoua $23.4^{\circ} \mathrm{C}$ and $23.9^{\circ} \mathrm{C}$ to Dem. The hydrographic network of the basin narrows upstream downstream. The relief consists of upstream basin plateaus, plains in the middle and downstream lowlands whose altitude varies between $600 \mathrm{~m}$ and average $880 \mathrm{~m}$. However, there are isolated ancient massifs whose peaks reach around $927 \mathrm{~m}$. The geology of the watershed consists of base for the most part [8]. The population is predominantly rural and relatively dense. The main economic activity remains artisanal gold mining although agriculture remains the main activity in the whole of Congo.

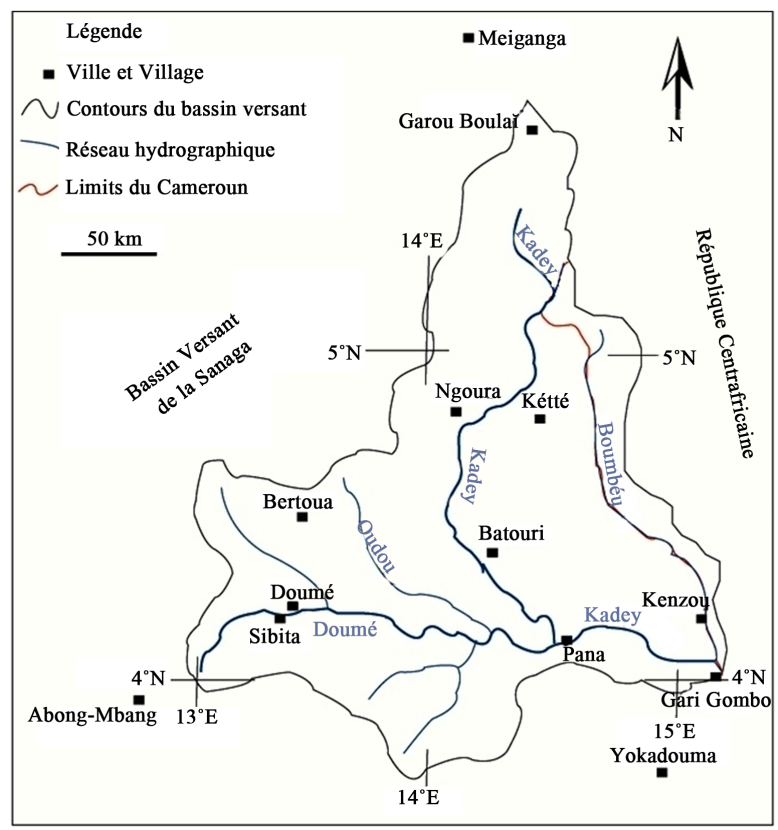

Figure 1. Location of catchment area of Kadey. 


\section{Data and Methods}

\subsection{Data Acquisition}

Rainfall data come from the service of the Agency's documentation for the Safety of Air Navigation in Africa and Madagascar (ASCENA) at the airport of Bertoua and the National Meteorology of Cameroon. They are recorded from 5 rainfall stations distributed over the basin and whose observations sizes vary from one station to another. The Longest chronicle (1969-2014) is recorded in the rainfall station in Bertoua, located in the North East of the basin. This long series will better appreciate the long-term rainfall variability.

Hydrometrics data are from the 1972-2013 period stations Bertoua and Batouri, extracted from the database of the hydrological research centre of Cameroon and field descents.

\subsection{Methods}

\subsubsection{Calculations of Rainfall and Hydrometrics Indices}

In time series, rainfall and hydrometric is evidence to identify the major trends. They are calculated by the method of weighted moving average filter or low-pass Hanning 2nd order.

To do this, we first proceed to data filtering to remove seasonal variations using the non-recursive low-pass filter Hanning 2nd order (it is a application of weighted moving averages). The implementation and determination of this filter is carried out by means of mathematical equations that permit to estimate each term in the series as follows:

$$
\begin{gathered}
x(t)=0.06 x(t-2)+0.20 x(t-1)+0.38 x(t)+0.25 x(t+1)+0.06 x(t+2) \\
\text { with: } 3 \leq t \leq(n-2)
\end{gathered}
$$

where: $x(t)$ is the total rainfall weighted for term $t, x(t-2)$ and $x(t-1)$ are observed total of two out above the term $t$ immediately, $x(t+2)$ and $x(t+1)$ are the observed total of two terms that follows the term $t$ immediately.

The weighted total of the first two $[x(1), x(2)]$ and the last two $[x(n-1), x(n)]$ terms of the series are determined by the following expressions ( $\mathrm{n}$ being the size series):

$$
\begin{aligned}
& x_{(1)}=0.54 x_{(1)}+0.46 x_{(2)} \\
& x_{(2)}=0.25 x_{(1)}+0.50 x_{(2)}+0.25 x_{(3)} \\
& x_{(n-1)}=0.25 x_{(n-2)}+0.50 x_{(n-1)}+0.25 x_{(n)} \\
& x_{(n)}=0.54 x_{(n)}+0.46 x_{(n-1)}
\end{aligned}
$$

To better visualize the periods of surplus and deficit in inter annual, the calculated moving averages have been centered and reduced from the following formula:

$$
\operatorname{Vcr}=\frac{(P-\bar{P})}{\sigma}
$$

With: $V c r$ is reduced centered variable (rainfall and hydrometric Index according to the studied variable), $P$ is the sum of the variable over a given period $t, \bar{P}$ is the average of the time series over the period of study and $\sigma$ is the standard deviation of the series on the study period.

\subsubsection{Ruptures Detection Tests in Time Series}

In this study, breaks tests permits to determine the various pivotal years of climate change in a watershed. Their roles come in supplement to rainfall and hydrometric evidence collected at weather stations. The existence of abrupt changes in hydroclimatic series is a possible cause of the heterogeneity of these series [9]-[12].

These tests are essentially based on the Bayesian method of Lee and Heghinian, Pettitt and segmentation Hubert [13] [14]. Tests Lee and Heghinian and Pettitt designed to detect breakage maximum while segmentation Hubert allows in turn to identify more if they exist in a time series data [15]-[17]. Their application is carried out using the KhronoStat 1.01 software developed by the French Institute of Research for Development (IRD).

\subsubsection{Estimated Periods of Rains Back around Breaks}

With HYFRAN 1.1 software developed by the Canadian Institute (INRS-ETE) and used here, we did a fre- 
quency analysis of rainfall totals on each break period to be identified. The goal is to determine any variation in the return period of a $P$ rain due to the rupture. The purpose of this calculation is to better assess the impact of climate variability on the choice of the rains (and flows) project in the design of hydraulic structures.

\subsubsection{Determination of the Magnitude Drought}

\section{1) SPI and ranges of values meaning}

In hydroclimatology, standard ranges of SPI index values used to assess the extent of moisture (or dryness) for each year of the time series. After this operation, it is possible to determine the number of years in line SPI and the corresponding meanings in terms of scale of the climate phenomenon (Table 1) from the following equation:

$$
A i=\left(\frac{n i}{N}\right)
$$

$A i$ is the percentage of the years concerned by the class $i$ (Table 1), ni is the number of years of class $i$ and $N$, the total number of years over the study period.

\section{2) Deficit (or excess) rainfall and hydrometric}

In the catchment area of the Kadey as in the whole of the Congo Basin, the dominant phenomenon throughout the time series is finally obtained for the SPI range for which we records the highest percentage.

Here, the magnitude of drought can also be assessed from the deficit calculation. For hydroclimatic for which variables time series presents a break, this method specifies the percentage change in the average around the break date [18]-[21]. This deficit is obtained by the following formula:

$$
D=\left[\left(\frac{x j}{x i}\right)-1\right] \times 100
$$

$D$ is the hydrometric or rainfall deficit, $x i$ is the average of the period before the break, $x j$ average for the period after the break.

\section{Results and Discussion}

\subsection{Hydrometric and Rainfall Indices}

Changing rainfall indices between 1960 and 2012 suggests three possible ruptures. Before the first break that marks the end of the 1960s, there have been positive rainfall indices. This is typical annual rainfall above the average interannual due to an excess rainfall regime during this period. For the 1970-1992 sequence, almost 90\% of the years concerned correspond to negative rainfall and hydrometric index reflecting a deficit rainfall pattern (Figure 2). A return to surplus occurs years after this deficit sequence in deficit until 2000. The decade 2010 is not yet complete, is characterized by alternating positive and negative indices. Subsequent monitoring of the rest of the series will better identify the trend of this decade.

\subsection{Tests of Rainfall and Hydrometric Breaks}

In deciding on the number of disruptions in rainfall to retain, the application of tests and Lee Heghinian, Pettitt (Table 2) have permited to detect a single break in 1969 while the segmentation Hubert has detected one in

\section{Table 1. Different classes indices SPI and their meanings.}

\begin{tabular}{ccc}
\hline $\mathrm{N}^{\circ}$ of Classes & Classes SPI & Interpretation \\
\hline 1 & $\mathrm{SPI}>2$ & Humidity extreme \\
2 & $1<\mathrm{SPI}<2$ & High humidity \\
3 & $0<\mathrm{SPI}<1$ & Moderate humidity \\
4 & $-1<\mathrm{SPI}<<0$ & Moderate drought \\
5 & $-2<\mathrm{SPI}<-1$ & With drought \\
6 & $\mathrm{SPI}<-2$ & Extreme drought \\
\hline
\end{tabular}




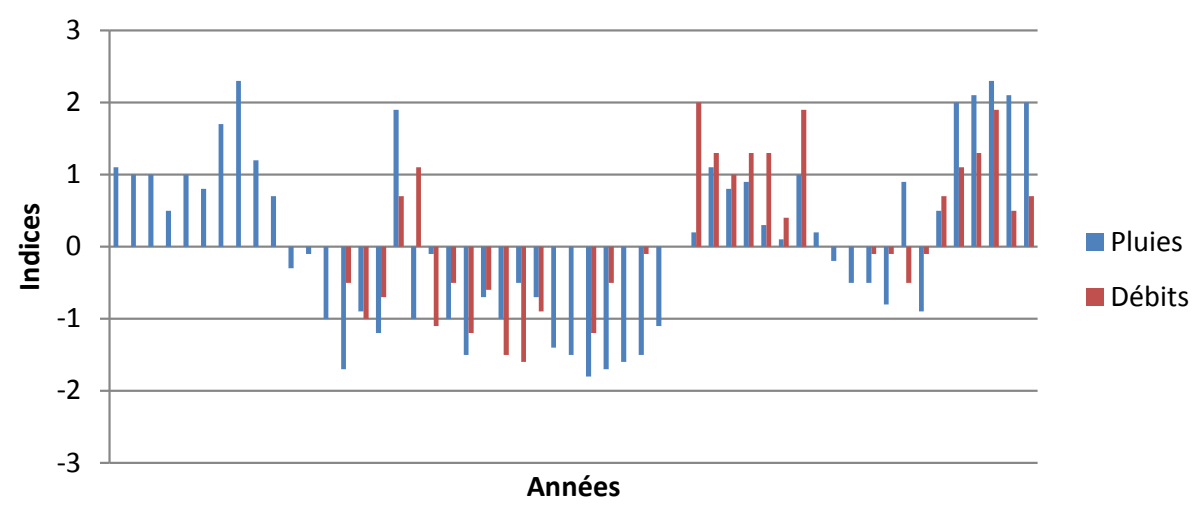

Figure 2. Indices of rainfall and hydrometric 1960-2013.

Table 2. Results of tests applied to breaking rainfall and hydrometric data.

\begin{tabular}{|c|c|c|c|c|c|}
\hline & Tests breaks & Year average or break & $\begin{array}{l}\text { Period before the } \\
\text { first break (mm) }\end{array}$ & $\begin{array}{l}\text { Average speed after } \\
\text { the first break }(\mathrm{mm})\end{array}$ & $\begin{array}{l}\text { Average speed after } \\
\text { the second break (mm) }\end{array}$ \\
\hline \multirow{3}{*}{$\begin{array}{c}\text { Rainfall } \\
(1960-2012)\end{array}$} & Lee e and Heghinian & 1969 & 1405 & 1117 & \multirow{6}{*}{1263} \\
\hline & Pettitt & 1969 & 1405 & 1117 & \\
\hline & Segmentation Hubert & $\begin{array}{c}{[1960-1969]} \\
{[1970-1991][1992-2012]}\end{array}$ & 1405 & 1034 & \\
\hline \multirow{3}{*}{$\begin{array}{l}\text { Hydrometry } \\
(1972-2012)\end{array}$} & Lee and Heghinian & 1988 & 27 & 59 & \\
\hline & Pettitt & 1992 & 31 & 75 & \\
\hline & Segmentation Hubert & [1992-2012] [1993-2012] & 31 & 75 & \\
\hline
\end{tabular}

1969 and another in 1992 in line with the indices previously observed. Ndam et al. (2016) in their study of the Sanaga and Mfochivé (2011) on the catchment area of So'o, observed rainfall ruptures between the years 1968 and 1970. This is also the case Kpoumié and al. (2009) on the Sangha basin. This breakdown shows that the catchment area of Kadey fits well in general changes in rainfall patterns observed in the late 1960s in Central Africa in general and in the Congo Basin in particular.

Breaks tests applied to hydrometric data (Table 2) confirmed a single break on the two observed from rainfall indices. That of Lee and Heghinian detected a break in 1988 while those of Pettitt and Hubert confirmed that of 1992. After the breaks as well as gauging rainfall observed in 1969 by Lebel and Vischel (2005); Servat et al. (1995); Goula et al. (2006) and by Mahe et al. (2000) in 1991, the 1988 break seems specific to data quality and tests used. On three tests applied, that of Lee and Heghinian is the only to detect.

\subsection{Variability of Recurrence Rains around Breaks}

The annual rainfall totals are, in general, the more important they are rare (Figure 3). So we can see that before the break of 1970, annual rainfall less than $1350 \mathrm{~mm}$ showed a recurrence of at least 1 time every 5 years (Figure 3(a)). Beyond this value, precisely from $1420 \mathrm{~mm}$, annual totals have long return periods (20 years) to very long (100 years). During the period 1970-1992, for the same return periods, annual rainfall has significantly decreased accumulation (Figure 3(b)). This is the case when there is a return of 3-year period before 1970. At this level, the cumulative rainfall of $1300 \mathrm{~mm}$ became centennial.

In short, we can say that the climate change that has occurred during the 1970s has had the impact of a variation of the recurrence of rainfall annually until 1992 on the whole basin. However, at the beginning of the 90s and especially after 1992, it is noted that the recurrence of annual rainfall has shifted to the behavior observed during the decade 60 (Figure 3(c)). This new trend reflects a rainfall recovery that seems to break the long “drought” highlighted by many authors [20] [22]-[25]. 


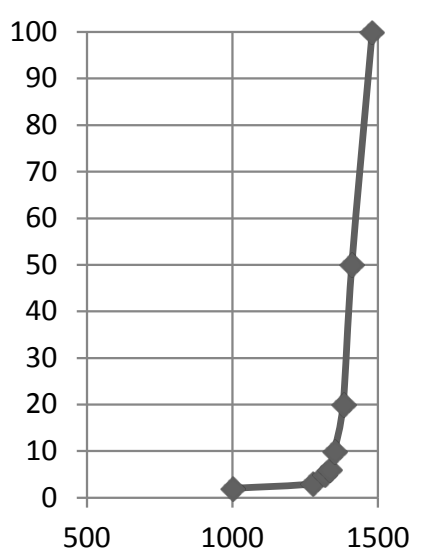

(a)

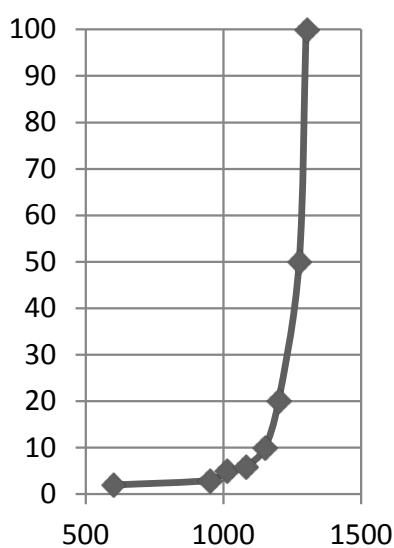

(b)

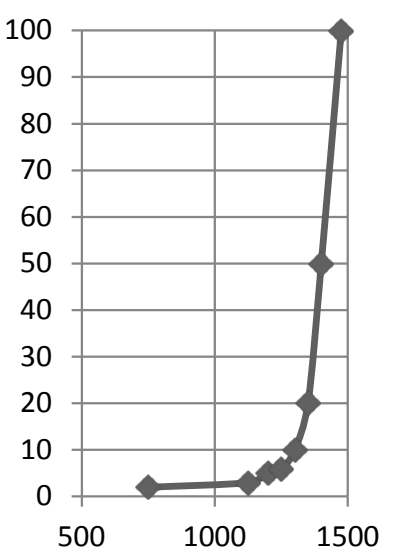

(c)

Figure 3. Impact of disruptions on the recurrence of rainfall annual rainfall; (a) period of 1960-1969, (b) 1970 to 1991 period and (c) period of 1992-2013.

\subsection{Extent of Drought}

\section{1) SPI and ranges of values meaning}

Fluctuating hydro data observed on the Kadey basin materialized by alternating wet and dry years as shown by the evolution of SPI indices. In this way, on the basis of these indices expressed by rainfall data for the study period (1960-2013), 25\% of years of observation have suffered a moderate drought and only $11 \%$ correspond to a severe drought plan. In contrast, we note that over the same period, $47 \%$ of years running under a moderate moisture regime and the remaining $17 \%$ correspond to a moisture content ranging from high to extreme (Table 3). On the pelvis, SPI expressed from flows are characteristic of a "drought" (42\%) from high (15\%) to moderate (27\%). The $58 \%$ of the remaining years undergoes moisture to varying degrees (Table 3 ).

Out of all the two hydroclimatical parameters, the "drought" has a generally moderate nature. However, a considerable number of years have suffered very heavy periods "drought", this number also appears higher for the flow.

\section{2) Deficit (or excess) rainfall and hydrometric}

Observations, we note: before 1970, the average annual rainfall is $1477 \mathrm{~mm}$. It increased to $1268 \mathrm{~mm}$ between 1970 and 1992. This corresponds to a deficit of about 14\% which is in the same range as that observed elsewhere in the other basins in South Cameroon [26]-[30]. After 1992, the trend has shifted to an excess of about 18, 5\% until 2008 and $20 \%$ in 2012. In contrast to rainfall, hydrometric series is truncated because it starts in 1972 and ends more or less between 2004 and 2005.

A break is observed in 1990 by the test Lee, but this is not confirmed by the two other rather that hold 1992 agreement with the rainfall. This rupture generated a gain of over $108 \%$ runoff. We can therefore infer that excess rainfall for $18,5 \%-20 \%$ or about $19 \%$, you get a $108 \%$ surge in flows is 5,5 times the rainfall surplus (Table 4). Everything resulting nonlinearity between rain and flow in the watershed Kadey as is the case in Equatorial area general and Southern Cameroon in particular [29]-[31].

\section{Conclusions}

The main purpose of this study was to better explain and understand climate variability to better assess its impact on surface runoff. Indeed, from 1960 to 2012, the climatic variability on watershed Kadey was characterized by two major breaks rainfall occurred in 1969 and 1992. The first break, characteristic of a scheme deficit has caused the loss of rainfall order of $14 \%$ and a scarcity of annual rains becoming stronger. The second rupture generated excess rainfall nearly $19 \%$ and an increase in the recurrence of heavy rains, reflecting a return to surplus trend. The hydrological response to this rainfall amount is over $100 \%$. In terms of number of years, drought nevertheless has a moderate nature. The present work is to highlight the non-linearity of the relationship between rainfall and flow in the equatorial areas.

In a medium- and maybe even in the short term, a more detailed analysis of the contribution of underground tanks with flow production process will better understand this relationship. 
Table 3. Extent of drought (and moisture) between 1960-2013.

\begin{tabular}{cccc}
\hline Variables & SPI ranges & Interpretation & \% Years \\
\hline Rainfall (1960-2013) & SPI $>2$ & High humidity & 4 \\
& $1<$ SPI $<2$ & Moderate humidity & 47 \\
& $0<$ SPI $<1$ & Moderate drought & 25 \\
$-2<$ SPI $<-1$ & With drought & 11 \\
Hydrometry (1972-2013) & HPI $>2$ & High humidity & 5 \\
& $1<$ SPI $<2$ & Moderate humidity & 29 \\
& $0<$ SPI $<1$ & Moderate drought & 24 \\
\hline
\end{tabular}

Table 4. Deficits (excess) rainfall and hydrometric around breaking years.

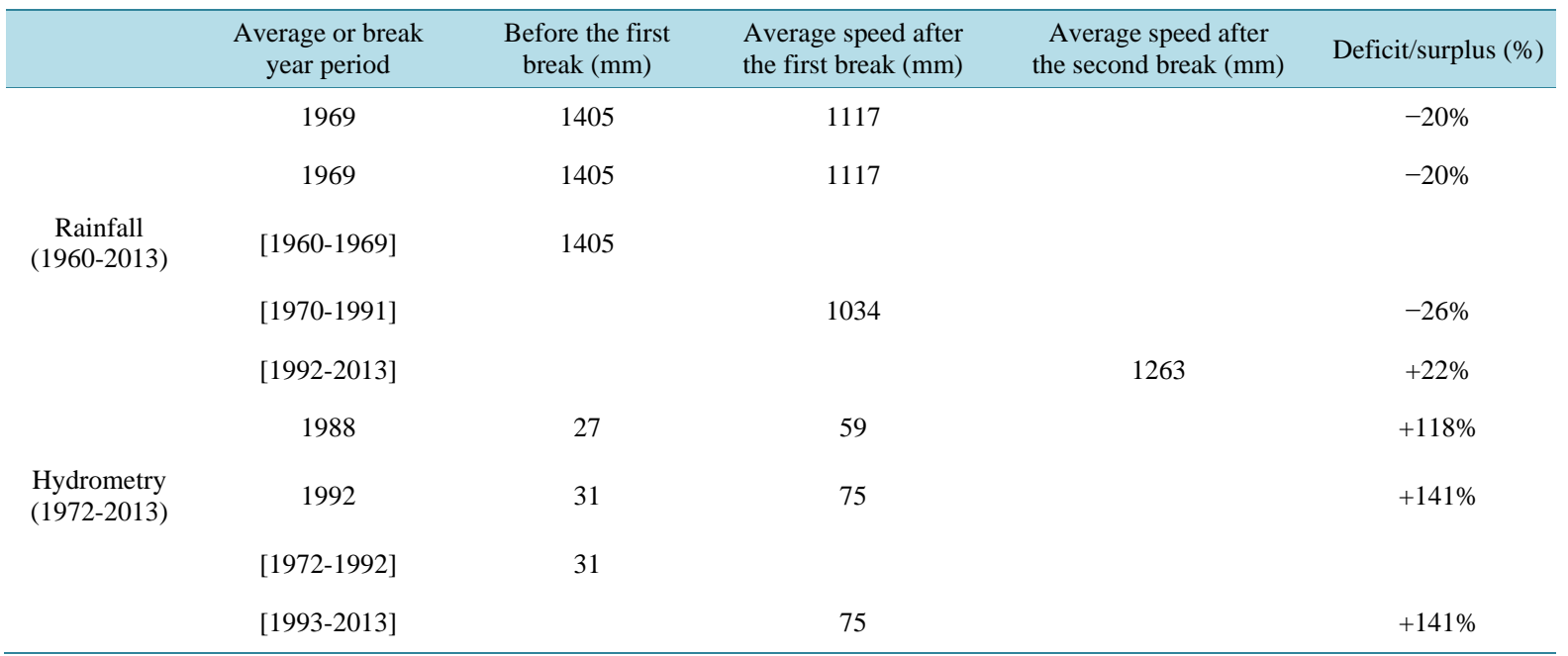

\section{Acknowledgements}

We thank the Hydrologic Research Centre and the National Meteorology Direction respectively for the flow and rainfall data used in this work. We thank Mireille Zebsa, Christelle Djomo and Mfochivé Oumarou for excellent research assistance, and Raïssa Dorette Matchonga, Levy Maxime and Bouelet Sandrine Isabelle for useful discussions. All authors contributed to the statistical analysis, drafting and critical review of the manuscript. The authors declare no competing financial interests.

\section{References}

[1] Mahé, G., Olivry, J-C., Dessouassi, R., Orange, D., Bamba, F. and Servat, E. (2000) Relation eaux de surface-Eaux souterraines d'une rivière tropicale au Mali. Comptes Rendus de l'Académie des Sciences, 330, 689-692. http://dx.doi.org/10.1016/s1251-8050(00)00188-9

[2] Sighomnou, D., Sigha Nkamdjou, L., Liénou, G., Dezetter, A., Mahé, G., Servat, E., Paturel, J.E., Olivry, J.C., Tchoua, F. and Ekodeck, G.E. (2007) Impacts des fluctuations climatiques sur le régime des écoulements du fleuve Sanaga au Cameroun, prospectives pour le XXIème siècle. In: Mahé, G., Ed., Climatic and Anthropogenic Impacts on the Variability of Water Resources, Technical Document in Hydrology 80, Paris, UNESCO, 173-182.

[3] Bricquet, J.P., Bamba, F., Mahé, G., Toure, M. and Olivry, J.C. (1996) Evolution récente des ressources en eau de 
l'Afrique atlantique. Revue des Sciences de l'Eau, 3, 321-337.

[4] Paturel, J.E., Servat, E., Kouame, B., Lubes-Niel, H., Fritsch, J.M. and Masson, J.M. (1997) Manifestation d'une variabilité hydrologique en Afrique de l'Ouest et centrale. IASH, 240, 21-30.

[5] Diello, P., Paturel, J.E., Mahé, G., Barbier, B., Karambiri, H. and Servat, E. (2006) Méthodologie et application d’une démarche de modélisation hydrologique prenant en compte l'évolution des états de surface en milieu sahélien d'Afrique de l’Ouest. In: Demuth, S., Gustard, A., Planos, E., Scatena, F. and Servat, E., Eds., Climate Variability and ChangeHydrological Impacts, IAHS Publ. 308, Wallingford, 691-697.

[6] Leduc, C., Favreau, G. and Schroeter, P. (2001) Long-Term Rise in a Sahelian Water-Table: The Continental Terminal in South-West Niger. Journal of Hydrology, 243, 43-54. http://dx.doi.org/10.1016/S0022-1694(00)00403-0

[7] Favreau, G., Leduc, C., Marlin, C. and Guero, A. (2002) Une dépression piézométrique naturelle en hausse au Sahel (Sud-Ouest du Niger). Comptes Rendus Geoscience, 334, 395-401. http://dx.doi.org/10.1016/S1631-0713(02)01763-7

[8] Ndam Ngoupayou, J.R., Braun, J.J., Meybeck, M. and Bedimo Bedimo, J.P. (1998) Réactualisation des données hydroclimatologiques des bassins fluviaux de la Sanaga et du Nyong (Sud Cameroun). In: Vicat and Bilong, Eds., Collect. GEOCAM, 2/1999, Presses Universitaires de Yaoundé, 51-64.

[9] PU-AMI (2014).

[10] Sigha-Nkamdjou, L., Sighomnou, D., Liénou, G., Ndam Ngoupayou, J.R., Bello, M., Kamgang, G.R., Ekodeck, G.E., Ouafo Mendo, M.R., Patural, J.E. and Servat, E. (2005) Impacts des modifications climatiques et anthropiques sur les flux de matières de quelques bassins fluviaux du Cameroun. In: Horowitz, A.J. and Walling, D.E., Eds., Sediment Budgets 2. IAHS Publication 292, IAHS Press, Wallingford, 291-298.

[11] Liénou, G., Mahé, G., Paturel, J.E., Servat, E., Ekodeck, G.E. and Tchoua, F. (2009) Variabilité climatique et transport de matières en suspension sur le bassin versant de Mayo-Tsanaga (Extrême-Nord Cameroun). Sécheresse, 20, 1-6.

[12] Kouakou, K.E. Goula, B.T.A. and Savane, I. (2007) Impacts de la variabilité climatique sur les ressources en eau de surface en zone tropicale humide: cas du bassin versant transfrontalier de la Comoé (Côte D’ivoire—Burkina Faso). Euro. Journal of Sciences Research, 16, 31-43.

[13] Lebel, T. and Vischel, T. (2005) Climat et cycle de l'eau en zone tropicale: Un problème d'échelle. Comptes Rendus Geoscience, 337, 29-38. http://dx.doi.org/10.1016/j.crte.2004.08.011

[14] Kpoumié, A., Ndam Ngoupayou, J.R., Rusu, E., Sfîca, L., Ichm, P. and Ekodeck, G.E. (2012) Spatiotemporal Evolution of Rainfall Regimes in the Sanaga Basin-Cameroon in Deficit Context. Present Environment and Sustainable Development Journal, 6, 55-68. http://pesd.ro/article/nr.6/2/06SEORRITSBCIADC151020125568.pdf

[15] Béléké (2007) Etudes piézométriques et caractérisation physico-chimiques des nappes en zone de socle cristallin: Cas du bassin versant de la Djadombé à Bertoua (Est-Cameroun), Mém. DEA, Université de Yaoundé 1, 87 p.

[16] Ndam Ngoupayou, J.R., Dzana, J.G., Kpoumie, A., Tanwi Ghogomu, R., Fouepe Takounjou, A., Braun, J.J. and Ekodeck, G.E. (2016) Present-Day Sediment Dynamics of the Sanaga Catchment (Cameroon): From the Total Suspended Sediment (TSS) to Erosion Balance. Hydrological Sciences Journal. http://dx.doi.org/10.1080/02626667.2014.968572

[17] Wu, H., Hayes, M.J., Wilhite, D.A. and Svoboda, M.D. (2005) The Effect of the Length of Recordons the Standardized Precipitation Index Calculation. International Journal of Climatology, 25, 505-520. http://dx.doi.org/10.1002/joc.1142

[18] L’Hôte, Y., Mahé, G., Some, B. and Triboule, J.P. (2002) Analysis of a Sahelian Annual Rainfall Index from 1896 to 2000; The Drought Continues. Journal of Hydrology, 47, 563-572. http://dx.doi.org/10.1080/02626660209492960

[19] Goula, B.T., Brou, K., Brou, T., Savané, I., Vamoryba, F. and Bernard, S. (2007) Estimation des pluies exceptionnelles journalières en zone tropicale: cas de la Côte d'Ivoire par comparaison des lois lognormale et de Gumbel. Hydrological Sciences Journal, 52, 49-67. http://dx.doi.org/10.1623/hysj.52.1.49

[20] Braun, J.J., Bedimo Bedimo, J.P., Robain, H., Nyeck, B., Ndam Ngoupayou, J.R., Viers, J., Dupré, B., Olivie-lauquet, G., Yene Atangana, Q. and Tankeu, A. (1998) Fonctionnement des écosystèmes tropicaux humides: Influences sur les ressources hydriques et la qualité des eaux, exemple du bassin fluvial du Nyong (Sud-Cameroun). In: Vicat, J.P. and Bilong, P., Eds., Collection GEOCAM, Presses Universitaires de Yaoundé, 23-40.

[21] Wotling, G., Mahé, G., L’Hôte, Y. and Le Barbé, L. (1995) Analyse par les vecteurs régionaux de la variabilité spatiotemporelle des précipitations annuelles liées à la mousson africaine. Veille Climatique Satellitaire; Ed. ORSTOM, Météo-France, No. 52, 58-73.

[22] Kamagaté, B. (2006) Fonctionnement hydrologique et origines des écoulements sur un bassin versant de milieu tropical de socle au Bénin: Bassin versant de la Donga (Haute Vallée de l’Ouémé). Thèse de Doctorat, Université de Montpellier II, Montpellier.

[23] Lebel, T. and Vischel, T. (2005) Climat et cycle de l'eau en zone tropicale: Un problème d'échelle. Comptes Rendus Geoscience, 337, 29-38. http://dx.doi.org/10.1016/j.crte.2004.08.011

[24] Mahé G. and Olivry J.C. (1995) Variations des précipitations et des écoulements en Afrique de l’Ouest et Centrale de 
1951 à 1989. Sécheresse, 6, 109-117.

[25] Kalnay, E., Kanamitsu, M. and Kistler, R. (1996) TheNCEP/NCAR 40-Year Reanalysis Project. Bulletin of the American Meteorological Society, 77, 437-471. http://dx.doi.org/10.1175/1520-0477(1996)077<0437:TNYRP>2.0.CO;2

[26] Matsindjou Djoumessi, V. (2004) Etude des caractéristiques physico-chimiques et piézométrie des nappes de la région d’Abong-Mbang, Mémoire de DEA, Université de Yaoundé I, Cameroun, 66 p.

[27] Servat, E., Paturel, J.E., Brou, K. and Boyer J.F. (1995) Manifestation de la sécheresse en Afrique de l'Ouest non sahélienne: Cas de la Côte d’Ivoire, du Togo et du Bénin. Sécheresse, 6, 95-102.

[28] Savané, I., Kapo, C. and Gion, P. (2001) Variabilité climatiques et ressources en eau souterraine dans la région semi montagneuse de Man. Sécheresse, 12, 232-237.

[29] Zebsa, M., Kouassy Kalédjé, P.S., Ndam Ngoupayou, J.R. and Mvondo Ondoua, J. (2014) Exploitations minières dans la région de l'Est-Cameroun: Facteurs de changements climatiques et risques d’insécurité alimentaire (cas spécifique de l'exploitation del'or à Batouri), Actes du $1^{\text {er }}$ Coll. Inter. Pluridisciplinaires de l’IUCSJD, 8-10 Janv 2014, Douala, Cameroun.

[30] Ndam Ngoupayou, J.R., Boeglin, J.-L., Bedimo Bedimo, J.P., Braun, J.-J., Amanabenogo, A. and Bineli, E.E. (2008) Influence of Climatic Variability and Anthropic Activities on the Water Resource of the Nyong Forestry Watershed in South Cameroon, in AMMA. 3rd International Conference, Ouagadougou, 20-24 July 2008, 516-517.

[31] Sigha, N.L., Sighomnou, D. and Bedimo Bedimo, J.P. (1998) Variabilité des régimes hydrologiques des cours d’eau de la bande méridionale du plateau sud-Camerounais. Publication AISH. No. 252-222. 